\title{
Promotion of flowering in conifers: from the simple application of a mixture of gibberellins to more integrated explanations
}

\author{
M. Bonnet-Masimbert
}

INRA Station d'Amélioration des Arbres Forestiers, Ardon, 45160 Olivet, France

\section{Introduction}

Flowering induction in trees is still an important problem for both the supply of seed and breeding programs, which have to face the long juvenile phase and irregular flowering so common in most forest trees. Many recent reviews indicate clearly that induction of flowering is now possible in many conifers in a more or less juvenile stage (Owens and Blake, 1985; Pharis and Ross, 1986; Pharis et al., 1987; Bonnet-Masimbert, 1987; Bonnet-Masimbert and Zaerr, 1987). In most cases, the treatments are based on the use of gibberellins (GAs), especially the mixture of GA4 and GA7, which were demonstrated to be the active gibberellins for Pinaceae species (Pharis, 1975).

However, the problem of stimulation and regulation of flowering in forest seed orchards is still far from a general solution. These difficulties are due to the fact that, in opposition to photoperiodic or thermoperiodic herbaceous plants, the flowering of woody perennial species involves undoubtedly a multifactorial regulation where environmental and physiological factors interact extensively. In fact, in order to get a more reliable response, the hormonal treatment of conifers has generally been associated with different kinds of cultural treatments. Thus, in the field, it is generally possible to enhance the natural flowering cycle of a tree in good years or in good flowering clones but it is still difficult in off years or with recalcitrant clones. In greenhouses, it is possible to have a better control of some of the environmental factors and to obtain more reproducible results. This is one reason why containerized indoor orchards are now proposed as a favorable alternative to conventional soil-based orchards (Ross et al., 1985).

The details of the various applied treatments will not be discussed in this review. They are amply documented in the previously quoted reviews. Owens and Blake (1985) presented a general review of all the reproductive processes from floral initiation to seed development. Pharis et al., (1987) paid special attention to the effect of exogenous applications of GAs and cultural treatments on variations in endogenous GAs. They discussed the specific 
and not pharmacological action of less polar GAs on flowering. Also, the relationship between flowering and shoot growth or bud vigor was discussed. Ross and Pharis (1987) presented recent concepts of sex expression in conifers. Other plant growth regulators (PGRs) were considered by Bonnet-Masimbert and Zaerr (1987). Practical treatments (i.e., techniques and doses of PGRs) are discussed by Bonnet-Masimbert (1987) and finally, Ross (1986) reviewed the effect of temperature on reproductive processes.

This paper will mainly report on relationships between GAs, other PGRs, growth characteristics of shoot and roots and some of the cultural treatments which can interfere with flowering. Special emphasis will be given to the present development of studies on flowering at the INRA research station (Ardon, France).

\section{Effect of cultural treatments on endo- genous growth regulators}

\section{Gibberellins}

Many of the commonly applied adjunct treatments can be interpreted as affecting root growth. One of these treatments, flooding of roots, stimulated flowering and synergized the GA4/7 effect on Douglas fir (Bonnet-Masimbert, 1982; Bonnel-Masimbert and Zaerr, 1987). Using rhizotrons, flooding was demonstrated to quickly stop root growth and the same was also observed after stem injection of GA4/7 (Bonnet-Masimbert, 1987). This suggested that reduced root growth might be favorable to flowering.

On tomato, root flooding reduced the general level of GAs in the roots, shoot and sap (Reid and Crozier, 1971). On Douglas fir, quantifying GAs by enzymelinked immunosorbent assay (ELISA). revealed no low polarity GAs after root flooding, whereas they were found up to 6 weeks after one stem injection of GA4/7 (Pilate, 1987). Both treatments produced the same floral response, which might mean that compounds other than GAs are also able to stimulate flowering or that flooding produced a deferred induction, possibly by retarding the differentiation of lateral apices as observed after root pruning (Owens et al., 1986).

On the contrary, Pharis et al., (1987) reported increases of less polar GAs after root pruning, girdling, nitrogen fertilization and drought. GiAs seem to vary promptly after either girdling (Wesoly, 1985) or heat treatment (Chalupka et al., 1982). In Norway spruce, Dunberg et al., (1983), demonstrated that covering the plants with a plastic film reduced the metabolism of [ $\mathrm{H}] \mathrm{GA} 4$ into other GAs. In Douglas fir, Pharis et al., (1987) also observed that, 10 weeks after root pruning, a much higher proportion of $\left[{ }^{3} \mathrm{H}\right] \mathrm{GA} 4$ was unmetabolized in pruned trees than in control trees $145 \%$ instead of $28 \%$ ). This indicates a long lasting effect of the treatments which create a rapid build up of less polar GAs. Recently, using immunological analysis instead of bioassays, Doumas et al., (1989) demonstrated on 3 year old cuttings of Douglas fir, 17 days after stem girdling, a drastic increase of some GAs, mainly a GA3-like peak, but no increase of less polar ones. Only trees having received GA4/7 exhibited significant levels of these GAs. These apparent differences between the experiments may be partly due to rapidly varying levels of GAs, but they confirm that most cultural treatments which have so far been analyzed have a direct effect on the level of GAs in the shoots of treated trees.

\section{Cytokinins}

From the work on many herbaceous plants, it appears that the levels of dif- 
ferent endogenous cytokinins (CKs), or their metabolism, change markedly at floral transition; sometimes only for a short period. Depending upon the species, the level may increase or decrease. Also, CKs are considered to be very important for sexual differentiation (Durand and Durand, 1984). Thus quantitative as well as qualitative variations must be analyzed. Curiously, little attention has been paid to CKs in relationship to flowering of conifers (Ross and Pharis, 1976; Tompsett, 1977) and it is only recently that endogenous CKs have also been considered (Taylor et al., 1984; Zaerr and Bonnet-Masimbert, 1987; Doumas et al., 1986; Imbault et al., 1988). Also, it is important to note that the biosynthesis of GAs may be affected by CKs (Coolbaugh, 1984).

In an experiment on Douglas fir, cytokinins were analyzed in shoots 3 and 6 weeks after the beginning of flooding treatments, GA4/7 injection or both (Pilate, 1987; Imbault et al., 1988). Isopentenyladenine (IP) increased markedly in shoots of all treated trees but especially in the trees which flowered the following spring. This might be interpreted as a reduced metabolism of IP forms into zeatin type. IP may also play a direct role in induction, since it was demonstrated that after its exogenous application female flowering was stimulated (imbault et al., 1988).

\section{Abscisic acid}

In the same experiment, Pilate (1987) observed an increase of abscisic acid $(A B A)$ in treated trees compared to controls, 3 weeks after treatment. This indicates that stress may accompany all the treatments, including the GA4/7 injection. Still, there seems to be no apparent relationship between $\mathrm{ABA}$ content and flowering response. Axillary apices were not observed, but this increase in $A B A$ may retard development or maintain the apices in a latent state as observed by Owens et al. (1986) after root pruning.

\section{Ethylene}

Finally, ethylene must also be considered. Yamamoto et al. (1987) demonstrated that flooding greatly increased the production of 1-amino-cyclopropane-1-carboxylic acid (ACC) in the roots and ethylene in the shoots of Pinus halepensis. In a recent experiment (Mercier, personal communication), Douglas fir cuttings were treated either by stem girdling or by root flooding at the end of shoot elongation. The level of $A C C$ and its malonyl form (MACC) increased rapidly in the shoots just after stem girdling and at the end of the flooding treatment. Flooding had an especially dramatic and long lasting effect, since 73 days after treatment the levels of ACC and MACC in the shoots were still much higher than in the control, however, Mercier (personal communication) observed their much lower levels in treated roots. Even if ethylene was not directly analyzed, an increased production after the treatments may be suspected.

Exogenous application of ethrel on some Cupressaceae species very strongly synergized the GA3 flowering effect but did not induce flowering itself (BonnetMasimbert, 1971). When applied to Douglas fir at the same time as GA4/7, ethrel had a detrimental effect on flowering compared to GA4/7 alone (Bonnet-Masimbert, 1983). This may be a question of improper timing, since treating Norway spruce with ethrel alone doubled the number of female cones (Remrod, 1976).

\section{Timing of flower initiation}

The proper timing of treatment application is crucial to successful flower induction for 
some temperate conifers (Owens and Blake, 1985). But whether the differentiation period is as narrow as was previousiy thought is now questionable. Most treatments are still applied as if initiation were a biological feature strictly related to, e.g., vegetative bud phenology or different phases of shoot elongation (Ross, 1983). This often improves the response to treatments with GAs. But is this relationship still true when cultural treatments are added to GAs? In Douglas fir, where initiation takes place normally in the spring around bud-burst (Owens, 1969), root pruning postponed initiation to the end of the growth period (Owens et al., 1986). Under natural conditions, initiation can even be obtained on lammas shoots (Bonnet-Masimbert and Lanares, 1978). In this case, the effect of severe summer water stress seemed to have initiated cone induction after meristematic activity resumed due to heavy rains in late summer, completely independently of the photoperiod.

\section{Possible biochemical markers}

Proper timing of treatments must be further redefined and knowledge of specific biochemical markers that are readily identifiable and sensitive at the earliest stages of flower induction are required. Specific techniques, such as immunocytochemical assays, have been applied at the meristematic level on some herbaceous angiosperms. However, within trees, only a small proportion of meristems will actually be converted into sexual buds. Even for shoots within the zone of sexual activity, large between-shoot variation is observed. This complex crown architecture of trees makes the sampling problem for biochemical studies on the early steps of flowering a crucial one. Another approach to this problem is to find a biochemical marker that is specific to the transition stage and, if possible, at the level of the shoot instead of the meristem. Certainly, protein analysis using the molecular biology tools could help, but so far it has not yet been done on flowering in conifers.

Recent studies in Douglas fir (Daoudi, 1988) indicated that some amines, like putrescine and tyramine, either free or in conjugated forms, might play such a role. In fact, during the rest period, when sexual buds were already differentiated, the ratio of free putrescine to free tyramine was 2-3 times higher in vegetative shoots than in shoots bearing male or female buds. Also, male bearing shoots had more neutral conjugates of putrescine in contrast to female bearing shoots which had more basic ones. A similar distribution was observed in tobacco (Cabanne et al., 1977).

These biochemical changes of early stages of initiation have yet to be verified in conifers. Certainly in some herbaceous plants (Cabanne et al., 1977; Martin-Tanguy et al., 1978, 1984) hydroxycinnamic acid amides not only gave an early indication of flowering initiation, but also they were able to stimulate flowering when applied exogenously. In apple trees, the exogenous application of putrescine, spermidine or spermine significantly increased the floral development (Rohozinski et al, 1986). Polyamines and ethylene syntheses interfered strongly with each other (Slocum et al., 1984) and also interacted with other PGRs, especially GAs (Dai et al., 1982) and CKs (Cho, 1983).

Finally, these polyamines also have a close relationship with ammoniacal nitrogen nutrition through arginine metabolism. In apple trees, ammoniacal fertilization only affects flowering after cessation of shoot elongation, whereas polyamines seem to have an effect independent of growth status (Rohozinski et al., 1986). 
Previous studies on Pinus eliotii (Barnes and Bengtson, 1968) clearly showed that the major effect of $\mathrm{NH}_{4} \mathrm{NO}_{3}$ fertilization in April and June primarily affects the arginine content (increases of $140 \%$ for arginine compared with only $15 \%$ for total nitrogen). Significant, positive correlations exist between free arginine content and fertilization and between female flowering and fertilization. Important clonal variations are observed. On the other hand, direct injection of arginine into branches of Douglas fir from the end of April to the end of June did not stimulate flowering (McMullan, 1980). It seems therefore that polyamines have to be studied further in relationship to vegetative growth and floral development as possible biochemical markers as well as active components of flowering.

\section{Conclusion}

From the few examples presented in this review, it is clear that all the factors affecting flowering, whether they are environmental, cultural or biochemical, interact extensively and that it is no longer possible to consider them separately. Certainly for conifers, GAs are major components in this process, but their biosynthesis and the interaction with biosynthetic pathways to other PGRs need to be more fully understood. There is one limit to the analysis of endogenous PGRs, regardless of the methodology used (i.e., bioassay or immunological methods): it is always very time consuming. This limits the number of samples which can be analyzed, especially since it is now clear that large numbers of analyses are necessary for precise kinetic studies. Emphasis has to be given to the development of well-adapted quick and precise methodologies for PGR analyses, especially the very difficult group of
GAs. Finally, much more has to be known on the effect of climatic conditions, i.e., temperature, light intensity, water supply, which make the tree able to respond or not to the so-called inductive treatments (Philipson, 1983). In view of the developing indoor containerized orchards, this will certainly be an important key to flowering success.

\section{Acknowledgments}

The author is grateful to Dr. J.W. Webber for fruitful discussions and for his kind help in improving the English version of this paper.

\section{References}

Barnes R.L. \& Bengtson G.V. (1968) Effect of fertilization, irrigation, and cover cropping on flowering and on nitrogen and soluble sugar composition of slash pine. For. Sci. 14, 172-180

Bonnet-Masimbert M. (1971) Induction florale précoce chez Cupressus arizonica et Chamaecyparis lawsoniana. Silvae Genet. 20, $82-90$

Bonnet-Masimbert M. (1982) Influence de l'état d'activité des racines sur la floraison induite par des gibbérellines 4 et 7 chez Pseudotsuga menziesii (Mirb.) Franco. Silvae Genet. 31, 178182

Bonnet-Masimbert M. (1983) Stimulation de la floraison chez les conifères: perspectives offertes par l'utilisation des régulateurs de croissance. Coll. COLUMA: Les substances de croissance et leur utilisation en agriculture, ACTA, Paris, 2, 480-486

Bonnet-Masimbert M. (1987) Floral induction in conifers: a review of available techniques. For. Ecol. Manage. 19, 135-146

Bonnet-Masimbert M. \& Lanares R. (1978) Induction florale sur pousses d'août chez le Douglas (Pseudotsuga menziesii). Can. J. For. Res. 8, 247-252

Bonnet-Masimbert M. \& Zaerr J.B. (1987) Hormonal control of tree growth. 2. The role of plant growth regulators in promotion of flowering. Plant Growth Regul. 6, 13-35 
Cabanne F., Martin-Tanguy J. \& Martin C. (1977) Phénolamines associées à l'induction florale et à l'état reproducteur de Nicotiana tabacum var. xanthi n.c. Physiol. Vég. 15, 429443

Chalupka W., Giertych M. \& Kopcewicz J. (1982) Effects of polyethylene covers, a flower inducing treatment, on the content of endogenous gibberellin-like substances in grafts of Norway spruce. Physiol. Plant. 54, 79-82

Cho S.C. (1983) Enhancement by putrescine of gibberellin-induced elongation in hypocotyls of lettuce seedlings. Plant Cell Physiol. 24, 305308

Coolbaugh R.C. (1984) Inhibition of ent-kaurene oxidation by cytokinins. J. Plant Growth Regul. 3, 97-109

Dai Y.R., Kauer-Sawhney R. \& Galston A.W. (1982) Promotion by gibberellic acid of polyamine biosynthesis in internodes of light-grown dwarf peas. Plant Physiol. 69, 103-105

Daoudi E.H. (1988) Identification et dosage des mono et polyamines chez le Douglas (Pseudotsuga menziesii) en liaison avec la sexualisation des rameaux. Mémoire de D.E.A., Université Paris VI

Doumas P., Bianco J. \& Bonnet-Masimbert M. (1989) Study of endogenous plant growth substances in Douglas fir. 1I. Gibberellin analysis. Forest Tree Physiology, Ann. Sci. For. 46 suppl., pp. 259s-263s

Doumas P., Morris J.W., Chien C., BonnetMasimbert M. \& Zaerr J.B. (1986) A possible relationship between a cytokinin conjugate and flowering in Douglas fir. In: 9th North American Forest Biology Workshop, June 1986, Oklahoma State Univ., Stillwater. pp. 285-296

Dunberg A., Malmberg G., Sassa T. \& Pharis R.K. (1983) Metabolism of tritiated gibberellins A4 and A9 in Norway spruce, Picea abies L. Karst. Plant Physiol. 71, 257-262

Durand R. \& Durand B. (1984) Sexual differentiation in higher plants. Physiol. Plant. 60, 267. 274

Imbault N., Tardieu I., Joseph C., Zaerr J.B. \& Bonnet-Masimbert M. (1988) Possible role of isopentenyladenine and isopentenyladenosine in flowering of Pseudotsuga menziesii: endogenous variations and exogenous applications. Plant Physiol. Biochem. 26, 289-295

Martin-Tanguy J., Cabanne F., Perdrizet E. \& Martin C. (1978) The distribution of hydroxycinnamic acid amides in plants. Phytochemistry $17,1927-1928$
Martin-Tanguy J., Margara J. \& Martin C. (1984) Phénolamides et induction florale de Chicorium intybus dans différentes conditions de culture en serre ou in vitro. Physiol. Plant. 61, 259-262

McMullan E.E. (1980) Effect of applied growth regulators on cone production in Douglas fir, and relation of endogenous growth regulators to cone production capacity. Can. J. For. Res. 10, 405-422

Owens J.N. (1969) The relative importance of initiation and early development on cone production in Douglas fir. Can. J. Bot. 47, 10391049

Owens J.N. \& Blake N.D. (1985) Forest tree seed production: a review of literature and recommendations for future research. Petawawa National Forest Institute. Canadian Forestry Service, Information Report P-I-X 53, pp. 161

Owens J.N., Webber J.E., Ross S.D. \& Pharis R.P. (1986) Interaction between gibberellin A4/7 and root pruning on the reproductive and vegetative processes in Douglas fir. Effects on lateral bud development. Can. J. For. Res. 16, 211-221

Pharis R.P. (1975) Promotion of flowering in conifers by gibberellins. For. Chron. 51, 244 248

Pharis R.P. \& Ross S.D. (1986) Hormonal promotion of flowering in the Pinaceae family conifers. In: Handbook of Flowering. (Halevy A., ed.), CRC Press, Boca Raton, FL. vol. 5, pp. 171-179

Pharis R.P., Webber J.B. \& Ross S.D. (1987) The promotion of flowering by gibberellins $A 4 / 7$ and cultural treatnnents: a review of the possible mechanisms. For. Ecol. Manage. 19, 65-84

Philipson J.J. (1983) The role of gibberellin $A 4 / 7$, heat and drought in the induction of flowering in Sitka spruce. J. Exp. Bot. 34, 291-302

Pilate G. (1987) Etude du rôle des phytohormones dans le développement végétatif et floral chez Pseudotsuga menziesii (Mirb.) Franco, par des méthodes immunoenzymatiques. Ph.D. Thesis, Université Paris VI

Reid D.M. \& Crozier A. (1971) Effect of waterlogging on the gibberellin content and growth of tomato plants. J. Exp. Bot. 22, 39-48

Remrod J. (1976) An experiment on flowerinduction with ethrel. In: Breeding Norway Spruce. Bogesund, pp. 203-205

Rohozinski J., Edwards G.R. \& Hoskyns P. (1986) Effect of brief exposure to nitrogenous compounds on floral initiation in apple trees. Physiol. Vég. 24, 673-677 
Ross S.D. (1983) Enhancement of shoot elongation in Douglas fir by gibberellin $A_{4 / 7}$ and its relation to the hormonal promotion of flowering. Can. J. For. Res. 13, 986-994

Ross S.D. (1986) Temperature influences on reproduction processes in conifers. In: Proc. Forest Climate 86: Symp. on Climate Applications in Forest Renewal and Forest Production. Nov. 1986, Orillia, Ont. in press

Ross S.D. \& Pharis R.P. (1976) Promotion of flowering in the Pinaceae by gibberellins. I. Sexually mature, non-flowering grafts of Douglas fir. Physiol. Plant. 36, 182-186

Ross S.D. \& Pharis R.P. (1987) Control of sex expression in conifers. In: Hormonal Control of Tree Growth. (S.V. Kossuth \& S.D. Ross, eds.), Plant Growth Regul. 6, 37-60

Ross S.D. Eastham A.M. \& Bower R.C. (1985) Potential for container seed orchards. In: Proc. Conifer Tree Seed in Inland Mtn. West Symposium, Missoula, Montana, USDA Forest Service (Shearer R.S., ed.), pp. 180-186

Slocum R.D., Kaur-Sawhney R. \& Galston A.W. (1984) The physiology and biochemistry of polyamines in plants. Arch. Biochem. Biophys. 235, 283-303

Taylor J.S., Koshioka M., Pharis R.P. \& Sweet G.B. (1984) Changes in cytokinin and gibberellin-like substances in Pinus radiata buds during lateral shoot initiation and the characterization of ribozyl zeatin and a novel ribozyl zeatin glycoside. Plant. Physiol. 74, 626-631

Tompsett P.B. (1977) Studies of growth and flowering in Picea sitchensis (Bong) Carr. 1. Effects of growth regulator applications to mature scions on seedling rootstocks. Ann. Bot. 41, 1171-1178

Wesoly W. (1985) Effect of girdling on flowering and on endogenous growth regulators in embryonic shoots of Scots pine grafts (Pinus silvestris). Acta Physiol. Plant. 7, 171-179

Yamamoto F., Kozlowski T.T. \& Wolter K.E. (1987) Effect of flooding on growth, stem anatomy, and ethylene production of Pinus halenpensis seedlings. Can. J. For. Res. 17, 69-79

Zaers J.B. \& Bonnet-Masimbert M. (1987) Cytokinin level and flowering in Douglas fir. For. Ecol. Manage. 19, 115-120 